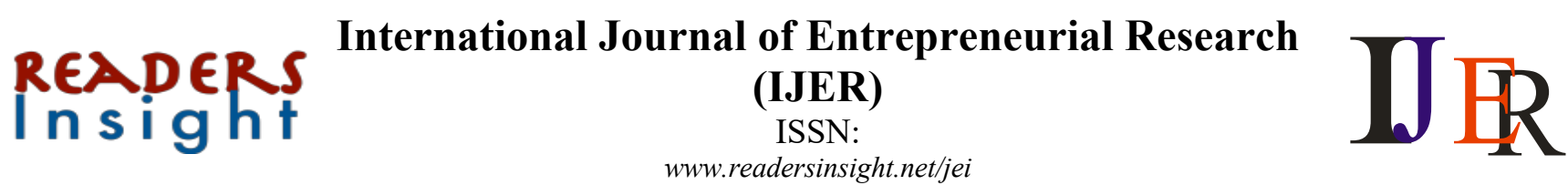

\section{Corporate Governance and Firm Performance Nexus: A Case of Cement Industry of Pakistan}

\author{
Abdul Ghafoor Kazi ${ }^{1 *}$, Muhammad Asad², Payal Devi Sahetiya ${ }^{3}$ \\ ${ }^{1,2,3}$ Department of Management Science, Shaheed Zulfikar Ali Bhutto Institute of Science and Technology, Hyderabad, Sindh, Pakistan \\ * Corresponding author: agkazi78@gmail.com
}

\begin{abstract}
Corporate governance is the system of rules, practices and method by that business corporations are directed and controlled. The aim of this research is to examine the impact of the corporate governance on the financial performance of the enlisted cement industry on the Pakistan Stock Exchange from the year 2013-17. This research is a "quantitative research" which focuses on numbers and results based on empirical analysis of actual data and logic. Ten out of seventeen cement firms listed at PSX from the period 2013-17 are selected as sample of the study. Data was collected from documents and records. Descriptive statistics, Pearson's correlation and multiple regressions were used for data analysis. The results showed that there is no significant relationship between leverage and firm performance, the board structure has no significant relationship with firm performance, and firm size has an insignificant relationship with firm performance. The results however suggested that ownership structure has significant relationship with firm performance. The future investors in cement industry of Pakistan must consider above factors before investments. This study helps shareholders and management in decision making about the effect of ownership structure on firm performance and how these can change ownership structure. This study helps students to gain knowledge and understanding about good corporate governance and its impact on firm performance. It will also help them to go through the annual reports of companies and to analyse the financial statements so that they could learn how to analyse the performance of the firm in terms of ROE. Moreover, the study would also be a direction for future researchers and students to further add value to the subject of corporate governance and firm performance.
\end{abstract}

Keywords: Corporate Governance, Firm Performance, Pakistan Cement Industry, Pakistan Stock Exchange, Return on Equity
ARTICLE INFORMATION

Received: 1 July 2018

Revised: 1 November 2018

Accepted: 13 November 2018

DOI:

10.31580/ijer.v1i1.140

\section{INTRODUCTION}

The huge requirement for corporate governance has arisen as a result of the enlarging concern regarding the non-compliance of financial reporting and accountability by board of directors and management impose the losses on investors particularly in developing countries because of financial crisis (Baydoun, Maguire, Ryan and Willet, 2013). Some countries lack corporate governance system (Ekanayake, Perera and Perera, 2010). Corporate governance is the system of rules, practices and method by that business corporations are directed and controlled. Company governance management and ruled the system for instance it controls the internal and external of managers and outside stakeholders still because it shows the relationships between company's management its boards and alternative stakeholders. By using corporate governance companies enhance the company's potential as well as the audacity of investors and allow by securing their interest moreover, it is a structure by which the several stakeholders' interest are balanced. In academic studies, the system of corporate governance has much importance and focus in developed as well as developing countries (Mallin, 2004).

Corporate governance system is well vital for firm's economic growth. Corporate governance plays an important role to create the financial value by enhancing the financial performance through ROA, ROE, EPS. Due to poor strategy, many businesses failed which leave bad impact on companies' financial performance that is why governance tools playing a wide role to run the business in a profitable manner. Codes of corporate governance are important for developing countries. In Pakistan codes of corporate governance are introduced by (SECP) Security and Exchange Commission of Pakistan in early March 2002. Corporate governance is concerning commitment to values and moral business conduct. It's concerning however organization is ruled. Accurate disclosure of information regarding the financial situations, performance, and governance of the corporate is main part of the corporate governance. This improves public understanding of the activities and policies of the organization. Corporate governance maintains, balance and strengthen the capital markets and also protect the investors. With the help of this system, companies improve their financial performance of firms and also develop the investments.

This research examines the effect of the corporate governance (ownership structure, board structure, leverage and firm size) on the firm performance of the cement industry enlisted on the Pakistan Stock Exchange from the year 2013 to 2017. In this study, firm performance is measured by return on equity (ROE).

\section{LITERATURE REVIEW}

\section{The Cement Industry in Pakistan}

The cement industry is one of the most important industries of Pakistan whom plays a critical role in the economic development of the 
Pakistan. Previously when Pakistan came into existence it had four cement plants that time but now twenty cement firms are operating in the cement industry of Pakistan. Cement industry of Pakistan is fulfilling the demand of cement and exporting the cement to the other countries for Instance: Sri Lanka, India, and Afghanistan, Russia and United Arab Emirates and some other African countries. Presently, Pakistan is ranked among the top 10 cement exporting countries.

The cement industry of Pakistan has an oligopoly market structure in which a few firms dominate. Whereas top five companies have controls over $55 \%$ of the market shares. The cement industry of Pakistan makes a significant contribution of Rs: 100 billion in the GDP (Gross Domestic Product) of Pakistan. This cement industry generates Rs 30 billion of tax revenue for the country. Production of the cement has been risen and the exports of cement industry has increased. The cement industry has the opportunity to get finance from the banks and other financial organizations in the country as it would be a growing industry. Cement industry is developing and it shows the bright future of the cement industry of Pakistan. This cement industry has the full capacity of exports.

\section{Ownership Structure}

Ownership Structure is the mean of managerial and general public ownership. General public ownership includes local and foreign individual investors other than directors, associated companies, public sector companies, banks and financial institutions, insurance companies, mutual funds and modaraba. It is the ratio of shares owned by the local and foreign investors to total outstanding common stocks. Managerial ownership includes directors, insiders and block holders of a business. It is the ratio of shares owned by the directors and officers of a company to total outstanding common stocks.

There are different ownership types which affects the performance of the firm differently. "General public ownership, managerial ownership, family ownership, institutional ownership and state ownership are some types of ownership". Ownership structure and corporate governance plays a very important role in the financial decisions of the firm (Butt, S. A., \& Hasan, A. 2009). Managers make less effort to control the firm due to the agency problem between shareholders and management. These issues can also cause managers to use the assets for their personal use. Increased shareholding by managers may help to limit the use of assets for their personal use. There are various studies which used the managerial ownership to check the impact of it on firm performance but the outcomes are mixed. $\mathrm{Hu}, \mathrm{Y}$. and Zhou, X. (2008) found that the firms with large managerial ownership have performed more efficiently than the firms with no managerial ownership. Therefore, there is a positive relationship between managerial ownership and firm performance (Rehman, R. ur, \& Mangla, I. U. 2012). In the meantime, managerial ownership has negative significant relationship with financial leverage $(\mathrm{D} / \mathrm{E})$ ratio (Butt, S. A., \& Hasan, A. 2009).

Institutional ownership is the ownership held by financial institutions and pension funds or endowments. There is not a positive observing role of institutional ownership in Pakistan. But some studies have found that institutional ownership has a strong relationship with firm performance. There is a positive significant relationship between institutional ownership and firm performance Sheikh, N. A., \& Karim, S. (2015).

H1: There is a significant relationship between Ownership Structure and Firm Performance (ROE) in cement industry of Pakistan.

\section{Board Structure}

Board structure is taken as a mean of board size, out-ratio and annual general meetings (AGM). Board size is a number of the board of directors, out-ratio is the ratio of non-executive and independent directors to total number of directors and in the AGM board of directors present annual report. This report shows the firm performance to shareholders and help in making important decisions related to the business.
The board size has significant effect on the firm performance. Different studies have different results with respect to increase and decrease in board size. Bigger board size is less effective than smaller board size because some directors could make sole profits on the basis of others (Lipton, M., \& Lorsch, J. W. 1992). Board size has negative relationship with firm performance (Yermack, D. 2005). As board size gets bigger, it is less effective to function than the smaller board size (Jensen, M. C. 1993). Hassan, M., \& Halbouni, S. (2013) have found that the board size has a negative relationship with firm performance. But different studies have also found that there is a positive relationship between board size and firm performance. There is positive significant relationship between board size and performance of the banks (AlSaidi, M., \& Al-Shammari, B. 2013).

Non-executive directors have the key role to improve the operations and to reduce the agency problem. Sarbanes Oxley Act as a code of corporate governance forces that the board size must include a significant portion of non-executive directors. Therefore, there are low chances that non-executive directors will work against the benefit of shareholders (Jensen, M. C. 1993). The ratio of non-executive directors in board size also have an impact on firm performance. There is a positive impact of independent directors on the performance of firm Omran, M. (2009). But some studies have also found that there is negative relationship between board composition and firm performance. Independent directors have negative relationship with firm performance (Agrawal, A., \& Knoeber, C. R. 1996). Annual general meeting (AGM) has negative significant relationship with corporate governance (Muhammad, B., Hayat, Y., Iqbal, M. M., \& Khan, S. 2016). Whereas, there is insignificant relationship between AGM and firm performance (Dar, L., Naseem, M. A., Niazi, G. S. K., \& Rehman, R. U. 2011).

Board structure is heavily depended on agency theory which focuses on the controlling ability of the board. Agency theory treats the business in a way that there is a mutual arrangement over which different members perform with each other (Jensen \& Meckling, 1976). As the assets are the resources of investors, the principal-agent problem can occur on the basis that management must decides in a way in which it can gain from the utilization of assets. Developing a governing body can be widely helpful to look after top management to analyse the problem and to reduce agency costs (Fama, 1983). Agency concept is used to determine the activities of directors which they do to improve the firm performance they govern (Jackling, 2009). Beside this, agency issue is not that much important for family-controlled firms because they have the focus to gain majority shareholding and therefore, they have enough strength and power to govern top management (Jensen \& Meckling, 1976).

$\mathrm{H} 2$ : There is a significant relationship between Board Structure and Firm Performance (ROE) in cement industry of Pakistan.

\section{Leverage}

Leverage is used by a firm to increase the return of an investment by using several financial instruments or borrowed capital. It is also the sum of debt used to finance assets. When a firm has high D/E ratio, it means that the firm has more debt than equity. The most common financial leverage ratio is debt-to-equity ratio. It is expressed as:

D/E Ratio = Total Debt $/$ Total Equity

Leverage is used to study the firm performance because it can impact on the relationship between corporate governance and firm performance (Chong-En, et. al, 2006). There is a positive significant relationship between leverage and firm performance (Khatab, H. et.al, 2011).

H3: There is a significant relationship between Leverage and Firm Performance (ROE) in cement industry of Pakistan.

\section{Firm Size}

Firm size is the total value of assets a firm have. We have taken natural logarithm of total assets in this study.

Firm size is used to study the firm performance because it can impact on the relationship between corporate governance and firm 
performance (Chong-En, et. al, 2006). Sheikh N. A. and Karim, S. (2015) have found that there is a negative relationship between leverage and firm performance. And the study also found that there is a positive relationship between firm size and firm performance.

H4: There is a significant relationship between Firm Size and Firm Performance (ROE) in cement industry of Pakistan.

\section{Firm Performance}

Return on equity is used in this study to measure the firm performance. It is net profit out of total owner's equity. It shows how much profit is earned by a firm on the basis of stockholders' capital.

$\mathrm{ROE}$ is represented as a percentage and calculated as:

Return on Equity $=$ Net Income / Owner's Equity

The practice of corporate governance is different in various countries due to their rules and regulations. CG also varies from industry to industry. The sound practices of corporate governance increase the value of a firm (Sheikh, N. A., \& Karim, S. 2015).

There are a lot of studies which have examined the relationship between corporate governance and firm performance and found that good corporate governance practices increase the performance of the firm by getting higher profit and mitigating systematic risk (Shleifer, 1997). Mitton (2001) took 398 firms of different countries like Korea, Malaysia, Indonesia and Thailand in his study and found that the corporate governance has a great impact on the performance of the firm at the time of East Asian Crisis in 1997 and 1998. The outcomes show that the firms with greater performance and worth tends to be better to disclose the quality information and the firms have more outside ownership which leads the firm to be more focused rather than improved.

Fich and Shivdasani, (2004) have found that firms with greater investment opportunities have higher market value and greater profitability. They report a positive securities exchange response when firms report investment opportunity plans for their executives. Ashraf and Ghani, (2005) studied about the variables that affect the development and improvement of accounting standards and experiences in Pakistan. They report that the absence of weak enforcement systems, investment assurance and legal inefficiencies are more important variables than the social factors in order to analyse the state of accounting in Pakistan. They assume that it is the necessity of the systems that are important in improving the calibre of accounting standard in developing countries. La Porta, et. al, (1999) stated that the investor's security has an ability to have a more value when the environment is legally stronger. Therefore, the investor's contribution has an ability to increase. They have found the positive relationship among corporate governance and firm performance. Drobetz, et. al, (2004) found that the German firms have the positive relationship between corporate governance and firm performance. Adjaoud (2007) used the 2002 rankings to examine the connection among the scores of corporate governance and firm performance respectively. They have discovered that there is no significant relationship between scores and firm's financial performance but there is significant relationship between scores and business quality included financial quality.

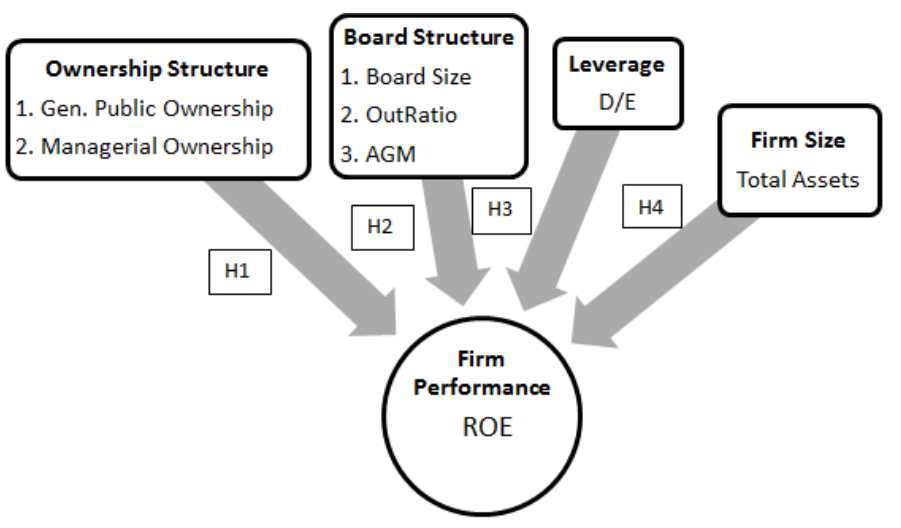

Figure 2.1: Conceptual Framework

\section{RESEARCH METHODOLOGY}

Research design is basically a framework or plan for a study which is used as guide in gathering and analysing the data. It is basically a blue print or outline of the research. This study is an exploratory research. In which the factors of corporate governance are explored that affects the firm performance. For this, yearly data from past five years is used. The data was tested and analysed on SPSS through regression, correlation and the relevant graphs. The ownership structure, board structure, leverage, and firm size are considered as the factors of the corporate governance whilst the return on equity shows the firm performance.

There are two types of research methods, deductive and inductive. This study does not attempt to develop new theories out of newly made hypothesis but attempts to validate the previously recognized relationships through other numerous researches, based on the recent data. Numerous other theories are already shaped concerning corporate governance factors inducing firm performance. This research has tested those theories by taking the most widespread corporate governance factors as independent variables and dependent variable as firm performance. Therefore, the method of this research is purely deductive.

Cement firms listed at PSX from the period 2013-2017 are taken as population of the study Table 3.1.

\begin{tabular}{|c|c|c|c|}
\hline s. \# & Cement Firms & S. \# & Cement Firms \\
\hline 1 & Attock Cement Pak Ltd. & 10 & \multirow{9}{*}{$\begin{array}{l}\text { Javedan Corporation Ltd. } \\
\text { Kohat Cement Co. Ltd. } \\
\text { Lucky Cement Limited. } \\
\text { Maple Leaf Cement Factory } \\
\text { Ltd. } \\
\text { Pioneer Cement Ltd. } \\
\text { Power cement Limited } \\
\text { Safe Mix Concrete Ltd. } \\
\text { Thatta Cement Company } \\
\text { Ltd. }\end{array}$} \\
\hline 2 & Bestway Cement Limited. & 11 & \\
\hline 3 & Cherat Cement Co. Ltd. & 12 & \\
\hline 4 & $\begin{array}{l}\text { D. G. Khan Cement Co. } \\
\text { Ltd. }\end{array}$ & 13 & \\
\hline 5 & Dewan Cement Limited. & 14 & \\
\hline 6 & Fauji Cement Co Ltd. & 15 & \\
\hline 7 & Fecto Cement Ltd. & 16 & \\
\hline 8 & $\begin{array}{l}\text { Flying Cement Company } \\
\text { Ltd. }\end{array}$ & 17 & \\
\hline 9 & Gharibwal Cement Ltd. & & \\
\hline
\end{tabular}

The study sample is selected through total sampling technique. Ten cement firms are selected through total population sampling, which is a kind of purposive sampling technique Table 3.2.

Table 3.2: Sample Size

\begin{tabular}{llll}
\hline S. \# & Selected Cement Firms & S. \# & Selected Cement Firms \\
\hline 1 & Lucky Cement Limited. & 6 & Pioneer Cement Ltd. \\
2 & Attock Cement Pak Ltd. & 7 & Fauji Cement Co Ltd. \\
3 & Bestway Cement Limited. & 8 & Fecto Cement Ltd. \\
4 & Cherat Cement Co. Ltd. & 9 & Kohat Cement Co. Ltd. \\
5 & $\begin{array}{l}\text { D. G. Khan Cement Co. } \\
\text { Ltd. }\end{array}$ & 10 & $\begin{array}{l}\text { Maple Leaf Cement Factory } \\
\text { Ltd. }\end{array}$ \\
\hline
\end{tabular}

The data was collected using documents and records, which consists of examining secondary data in the form of databases, meeting minutes, reports, attendance logs, financial records, newsletters, etc.

Data must be cleaned, coded and properly analysed. The tool used in this study was SPSS (statistical package for social sciences) in which multiple regression and correlation between variables were performed to analyse the data, describe the relationship among variables and reach the conclusion.

The research model used in this study is:

$\mathrm{Y}=\alpha+\beta_{\mathrm{X}}+\mu$

Where,

"Y" is a variable which is dependent.

" $\alpha$ " is a constant.

" $\beta$ " is a coefficient of independent variables.

" $\mathrm{x}$ " is an independent variable.

" $\mu$ " is an Error term.

Based on the selected variables, the multiple regression equation of the study is as, 
Firm Performance $(\mathrm{ROE})=\alpha+\beta$ (ownership structure $)+\beta$ (Board Structure $)+\beta($ Leverage $)+\beta($ Firm Size $)+\mu$

\section{DATA ANALYSIS}

Table 4.1 delineates the descriptive statistics. It indicates the minimum, maximum and standard deviation of the variables.

Table 4.1: Descriptive Statistics

\begin{tabular}{lccccc}
\hline & N & Min. & Max. & Mean & $\begin{array}{l}\text { Std. } \\
\text { Deviation }\end{array}$ \\
\hline $\begin{array}{l}\text { Firm } \\
\begin{array}{l}\text { Performance } \\
\text { (ROE) }\end{array}\end{array}$ & 50 & 9.70 & 128.44 & 31.6206 & 24.88543 \\
$\begin{array}{l}\text { Ownership } \\
\text { Structure }\end{array}$ & 50 & 2.25 & 41.21 & 16.7617 & 12.49639 \\
$\begin{array}{l}\text { Board Structure } \\
\text { Leverage }\end{array}$ & 50 & 23.38 & 34.29 & 29.6523 & 3.53097 \\
$\begin{array}{l}\text { Firm Size } \\
\text { Valid N (listwise) }\end{array}$ & 50 & .00 & 119.14 & 30.2258 & 24.43456 \\
\hline
\end{tabular}

The mean represents average value and the standard deviation shows the deviation of values around the mean. Whereas the $\mathrm{N}$ in the table shows total number of sample i.e. 50 .

ROE has minimum value 9.7 and maximum 128.44. The mean of ROE is 31.62 and standard deviation is 24.88 . Ownership structure has 2.25 and 41.21 minimum and maximum values with mean of 16.76 and standard deviation of 12.49. Board Structure has value as minimum i.e. 23.38 and maximum 34.29 with mean value of 29.65 and 3.53 of standard deviation. Leverage has minimum value of 0.00 and maximum 119.14 with mean 30.22 and standard deviation of 24.43 . Firm Size has minimum value 21.34 and maximum value 25.4 with mean 23.81 and standard deviation of 1.00 .

The correlation coefficient is a measure of relationship which is denoted by ' $r$ '. It tells the relationship between two or more variables whether there is positive, negative or no relationship at all. It also shows that how much strong or weak the relationship is? The value of ' $r$ ' lies between -1 and +1 . The value of $r$ can be interpreted as:

Exactly -1.Means there is a perfect negative relationship between variables.

-0.70. It means there is a strong negative relationship between variables.

-0.50. It shows that there is moderate negative relationship among variables.

-0.30. It means there is weak negative relationship between variables.

0. Means there is neither positive nor negative relationship among variables.

+0.30. It shows a weak positive relationship between variables.

+0.50. It means that there is a moderate positive relationship among variables.

+0.70. It shows a strong positive relationship between variables.

Exactly +1 . Variables have perfect positive relationship with each other.

Table 4.2 shows the correlation between leverage and ROE is - .023 that suggests leverage has very weak negative relationship with ROE. The correlation between firm size and ROE is -.256, it means they have weak negative relationship. When firm size rises the value of ROE declines or vice versa. There is a negative significant relationship between ownership structure and firm performance (ROE) with correlation and $p$ value of -.301 and 0.034 respectively. This means that the increase in ownership structure will decrease the performance (ROE) of the firm or vice versa. Board structure has weak positive relationship with firm performance (ROE) and the value of correlation is 0.032 .

The relationships between independent variables are such that ownership structure has positively significant relationship with board structure and has weak negative relationship with leverage $(D / E)$ and firm size (total assets). Board structure has negatively significant relationship with firm size and negative relationship with leverage. Leverage has positively significant relationship with firm size. The extension of linear regression is known as multiple regression. It is used when we have two or more independent variables. With the help of it we can estimate the value of dependent variable based on the value of independent variables. The main advantage of using multiple regression is that the overall fit of the model and contribution of each variable to the total variance is only explained by it. The acceptance or rejection of the hypothesis is based on the results of multiple regression.

\begin{tabular}{|c|c|c|c|c|c|}
\hline & ROE & $\begin{array}{l}\text { Ownership } \\
\text { Structure }\end{array}$ & $\begin{array}{l}\text { Board } \\
\text { Structure }\end{array}$ & Leverage & $\begin{array}{l}\text { Firm } \\
\text { Size }\end{array}$ \\
\hline $\begin{array}{l}\text { Firm } \\
\text { Performance } \\
\text { (ROE) }\end{array}$ & 1 & & & & \\
\hline $\begin{array}{l}\text { Ownership } \\
\text { Structure }\end{array}$ & $-.301^{*}$ & 1 & & & \\
\hline $\begin{array}{l}\text { Board } \\
\text { Structure }\end{array}$ & .032 & $.473^{* *}$ & 1 & & \\
\hline $\begin{array}{l}\text { Leverage } \\
\text { Firm Size }\end{array}$ & $\begin{array}{l}-.023 \\
-.256\end{array}$ & $\begin{array}{l}-.145 \\
-.079\end{array}$ & $\begin{array}{l}-.273 \\
-.445^{* *}\end{array}$ & $\begin{array}{l}1 \\
324^{*}\end{array}$ & 1 \\
\hline
\end{tabular}

${ }^{*}$. Correlation is significant at the 0.05 level (2-tailed).

**. Correlation is significant at the 0.01 level (2-tailed).

The table 4.3 of multiple regression shows the variable entered and variables removed. All the variables were entered at the same time and no variable was removed. The method used was "enter method" which indicates type of multiple regression i.e. standard

\begin{tabular}{|c|c|c|c|}
\hline Model & Variables Entered & $\begin{array}{l}\text { Variables } \\
\text { Removed }\end{array}$ & Method \\
\hline 1 & $\begin{array}{c}\text { Firm Size, Ownership } \\
\text { Structure, Leverage, Board } \\
\text { Structure }^{\mathrm{b}}\end{array}$ & . & Enter \\
\hline
\end{tabular}

The table 4.4 represents $\mathrm{R}, \mathrm{R}$ square and adjusted $\mathrm{R}$ square. Which shows correlation and variance among variables. As per the results, the .176 variance in firm performance (ROE) is due to the changes of these four predictors Ownership Structure, Board Structure, Leverage and Firm Size. $\mathrm{R}$ is .420 which shows the relationship between Firm Performance (ROE) and other four predictors is moderate which means the shared variance is a fit model.

Table 4.4: Model Summary

\begin{tabular}{|c|c|c|c|c|c|c|c|c|c|}
\hline \multirow[b]{2}{*}{$\begin{array}{l}\text { Mod } \\
\text { el }\end{array}$} & \multirow[b]{2}{*}{$\mathbf{R}$} & \multirow[b]{2}{*}{$\begin{array}{l}\text { R } \\
\text { Squa } \\
\text { re }\end{array}$} & \multirow[b]{2}{*}{$\begin{array}{l}\text { Adjust } \\
\text { ed } R \\
\text { Squar } \\
\text { e }\end{array}$} & \multirow[b]{2}{*}{$\begin{array}{l}\text { Std. } \\
\text { Error } \\
\text { of the } \\
\text { Estim } \\
\text { ate }\end{array}$} & \multicolumn{5}{|c|}{ Change Statistics } \\
\hline & & & & & \begin{tabular}{|l}
$R$ \\
Squa \\
re \\
Chan \\
ge
\end{tabular} & $\begin{array}{l}\text { F } \\
\text { Chan } \\
\text { ge }\end{array}$ & $\begin{array}{l}\text { df } \\
1\end{array}$ & $\begin{array}{l}\text { df } \\
2\end{array}$ & $\begin{array}{l}\text { Sig. F } \\
\text { Chan } \\
\text { ge }\end{array}$ \\
\hline 1 & $\begin{array}{l}.42 \\
0^{\mathrm{a}}\end{array}$ & .176 & .103 & $\begin{array}{l}23.568 \\
72\end{array}$ & .176 & 2.407 & 4 & $\begin{array}{l}4 \\
5\end{array}$ & .063 \\
\hline
\end{tabular}

As shown in table 4.5, standardized Beta of ownership structure is -.364, indicating moderate contribution in explaining the variation in firm performance (ROE). And the $t$ value and significance (p) value which is -2.332 and .024 respectively; this $p$ value being less than 0.05 . The result shows that there is moderate negative significant relationship between ownership structure and firm performance (ROE). This is presumably due to the fact that when ownership structure increases in terms of managerial and general public ownership, the overall control and effective decision-making decreases which adversely affects the overall financial health and profitability. It also motivates investors to invest in those firms where ownership structure is limited or at optimum level. This leads to the result that hypothesis $\mathrm{H} 1$ is accepted.

Table 4.5 shows that board structure accounts for .102 changes in Firm Performance (ROE) and its $t$ value and $p$ value are .583 and .563 
respectively. Result shows that board structure has weak positive but insignificant relationship with firm performance. This may be interpreted as such that board structure (board size, out-ratio and AGM) does not have significant impact on the performance of the firm. Leads to the results that hypothesis $\mathrm{H} 2$ is rejected.

There's a variation in the value of Firm Performance (ROE) due to leverage (D/E) i.e. 0.033 . And the t value and $\mathrm{p}$ value are .226 and .822 which is more than 0.05 (Table 4.5). Result shows that there is weak negatively insignificant relationship between leverage and firm performance. This means that leverage $(\mathrm{D} / \mathrm{E})$ is stable or at optimum level due to which it does not impact the performance (ROE) of the firm. Hence leads to the result that hypothesis H3 is rejected.

The firm size (total assets) accounts for -.251 changes in firm performance (ROE) and its $t$ value is -1.587 and $p$ value is .120 (Table 4.5). According to the results, there is negatively insignificant relationship between firm size and firm performance. This means that no matter what the firm size is; it does not impact the performance of the firm. These values lead to the result that hypothesis H4 is rejected.

\begin{tabular}{|c|c|c|c|c|c|c|c|c|}
\hline \multirow{2}{*}{\multicolumn{2}{|c|}{ Model }} & \multicolumn{2}{|c|}{$\begin{array}{c}\text { Unstandardiz } \\
\text { ed } \\
\text { Coefficients }\end{array}$} & \multirow{2}{*}{$\begin{array}{c}\begin{array}{c}\text { Standardiz } \\
\text { ed } \\
\text { Coefficient } \\
s\end{array} \\
\\
\text { Beta }\end{array}$} & \multirow{2}{*}{$\mathbf{t}$} & \multirow{2}{*}{$\begin{array}{l}\text { Si } \\
\text { g. }\end{array}$} & \multicolumn{2}{|c|}{$\begin{array}{c}95.0 \% \\
\text { Confidence } \\
\text { Interval for B }\end{array}$} \\
\hline & & B & $\begin{array}{l}\text { Std. } \\
\text { Error }\end{array}$ & & & & \begin{tabular}{|c|} 
Lowe \\
$r$ \\
Boun \\
$d$
\end{tabular} & $\begin{array}{l}\text { Upper } \\
\text { Boun } \\
\text { d }\end{array}$ \\
\hline & $\begin{array}{c}\text { (Consta } \\
\text { nt) }\end{array}$ & $\begin{array}{c}169.9 \\
19\end{array}$ & $\begin{array}{c}111.8 \\
01\end{array}$ & & $\begin{array}{c}1.52 \\
0\end{array}$ & $\begin{array}{c}.13 \\
6\end{array}$ & $\begin{array}{c}55.25 \\
9\end{array}$ & $\begin{array}{c}395.0 \\
97\end{array}$ \\
\hline 1 & $\begin{array}{l}\text { Owners } \\
\text { hip } \\
\text { Structur } \\
\text { e } \\
\text { Board }\end{array}$ & -.725 & .311 & -.364 & $\begin{array}{c}- \\
2.33 \\
2\end{array}$ & $\begin{array}{c}.02 \\
4\end{array}$ & $\begin{array}{c}- \\
1.351\end{array}$ & -.099 \\
\hline & Structur & .717 & 1.229 & .102 & .583 & $\begin{array}{c}.56 \\
3\end{array}$ & $1 . \overline{759}$ & 3.192 \\
\hline & $\begin{array}{c}\text { Leverag } \\
\mathrm{e}\end{array}$ & .033 & .148 & .033 & .226 & $\begin{array}{c}.82 \\
2\end{array}$ & -.264 & .331 \\
\hline & $\begin{array}{l}\text { Firm } \\
\text { Size }\end{array}$ & -6.230 & 3.927 & -.251 & $\begin{array}{c}1.58 \\
7 \\
\end{array}$ & $\begin{array}{c}.12 \\
0\end{array}$ & $\begin{array}{c}- \\
14.13 \\
9 \\
\end{array}$ & 1.678 \\
\hline
\end{tabular}

a. Dependent Variable: Firm Performance (ROE)

\section{CONCLUSION}

There are still many studies have been undergoing for determining the relationship between corporate governance systems and firm's financial performance measures. However, the results of these studies are mixed. This study analysed the relationship between firm performance (ROE) as a dependent variable and corporate governance systems (ownership structure, board structure, leverage and firm size) as independent variables. For data collection and examination, we took 10 cement firms enlist edon Pakistan Stock Exchange for the period of 5 years i.e. 2013-17.

As it is known that the cement industry has a significant portion in the development of the economy. If the cement industry performs efficiently, the economy will tend to be increase. In order to analyse the performance of cement industry (ROE), this research project explored the corporate governance systems which are highly responsible for the financial performance (ROE) of cement industry. The study overall depicts mixed results because Pakistan is a developing country and there are sound codes of corporate governance but its implementation is poor. The regulatory authorities should instruct the cement firms to follow the strict codes of corporate governance by making its implication stronger.

It is expected that the thesis would be of great help and assistance to shareholders and management of cement industry in their decision making with respect to corporate governance and the performance of the firm. This study helps shareholders and management about the effect of ownership structure on firm performance (ROE) and how they can change ownership structure and make effective decisions for better firm performance. This study helps them to better understand the importance of good corporate governance and the impact of this on firm performance. This study helps students to gain knowledge and understanding about good corporate governance and its impact on firm performance. It will also help students to go through the annual reports of companies and to analyse the financial statements so that they could learn how to analyse the performance of the firm in terms of ROE.

Since the firm performance has an influence of both factors internal as well as external, but this study only focuses on internal corporate governance factors. Furthermore, this research did not include few variables like institutional ownership, board's compensation, CEO duality and ROA. Changes in these factors may also affect the performance of the firm so the findings in this research will not be $100 \%$ suitable to rely on, however, it does provide an insight into the internal analysis of firm performance. Further research can be done by taking other corporate governance factors which can affect the firm's performance such as board's compensation, CEO duality and institutional ownership as independent variables and firm's performance (ROA or EPS) as a dependent variable. Industry other than cement sector could also be taken as a sample of the study.

\section{References}

Adjaoud, F. Z. (2007). The effect of Board's Quality on Performance: A Study of Canadian Firms', Corporate Governance. An International Review, 15(4), 623-635.

Agrawal, A., \& Knoeber, C. R. (1996). Firm Performance and Mechanisms to Control Agency Problems between Managers and Shareholders. The Journal of Financial and Quantitative Analysis, 31 (3), 377.

Al-Saidi, M., \& Al-Shammari, B. (2013). Board composition and bank performance in Kuwait: an empirical study. Managerial Auditing Journal, 28 (6), 472-494.

Ashraf, j., \& Ghani, I. (2005). Accounting in a Country: A Case of Pakistan. CMER Working Paper, 5(40).

Baydoun, N., Maguire, W., Ryan, N., \& Willett, R. (2013). Corporate governance in five Arabian Gulf countries, Managerial Auditing Journal, 28 (1), 7-22.

Butt, S. A., \& Hasan, A. (2009). Impact of ownership structure and corporate governance on capital structure of Pakistani listed companies. International Journal of Business \& Management, 4 (2).

Chong-En, B., Qiao, L., Joe, L., Frank M., S., \& Junxi, Z. (2006). An Empirical Study on Corporate Governance and Market Valuation in China. Frontiers of Economics in China, l (1), 83-111.

Dar, L., Naseem, M. A., Niazi, G. S. K., \& Rehman, R. U. (2011). Corporate governance and firm performance: A case study of Pakistan oil and gas companies listed in Karachi stock exchange. Global Journal of Management and Business Research, 11 (8).

Drobetz, W., Schillhofer, \& Zimmermann, H. (2004). Corporate governance and expected stock returns: evidence from Germany'. European Financial Management, 267-93.

Ekanayake, A., Perera, H., \& Perera, S. (2010). Contextual relativity of the role of accounting in corporate governance: evidence from the banking industry in Sri Lanka. The Sixth Asia Pacific Interdisciplinary Research in Accounting Conference, Sydney, 1-27,

Fama, E. F. (1983). Separation of Ownership and Control. journals of law and economics, 26(2), 301-325.

Fich, E., \& Shivdasani, A. (2004). The Impact of Stock-option Compensation for Outside Directors on Firm Value. Journal of Business, 78(6), 22292254.

Hassan, M., \& Halbouni, S. (2013). Corporate governance, economic turbulence and financial performance of UAE listed firms. Studies in Economics and Finance, 30 (2), 118-138.

$\mathrm{Hu}, \mathrm{Y} .$, \& Zhou, X. (2008). The performance effect of managerial ownership: Evidence from China. Journal of Banking \& Finance, 32 (10), 20992110.

Jackling, B. \&. (2009). Board Structure and Firm Performance: Evidence from India's Top Companies. Corporate Governance: An International Review, 17(4), 492-509.

Jensen, M. C. (1993). The Modern Industrial Revolution, Exit, and the Failure of Internal Control Systems. The Journal of Finance, 48 (3), 831.

Jensen, M., \& Meckling, W. (1976). Theory of the Firm: Managerial Behavior, Agency Costs and Ownership Structure. Journal of Financial Economics, 3(4), 305-360.

Khatab, H., Masood, M., Zaman, K., Saleem, S., \& Saeed, B. (2011). Corporate governance and firm performance: A case study of Karachi stock 
market. International Journal of Trade, Economics and Finance, 2 (1), 39.

La Porta, Lopez-de-Silanes, Shleifer, A., \& Vishny, R. (1999). Lega Determinants of External Finance. Journal of Finance, 54, 1131-1150.

Lipton, M., \& Lorsch, J. W. (1992). A modest proposal for improved corporate governance. The Business Lawyer, 59-77.

Mallin, C. A. (2004). Corporate governance, 1th edn, Oxford University Press, Incorporated.

Mitton, T. (2001). A Cross-section Analysis of the impact of Corporate Governance on the East Asian Crisis'. Marriat School, Brigham University.

Muhammad, B., Hayat, Y., Iqbal, M. M., \& Khan, S. (2016). Perceived Effect of Shareholders on Corporate Governance (SSRN Scholarly Paper No. ID 2737853). Rochester, NY: Social Science Research Network.

Omran, M. (2009). Post-privatization corporate governance and firm performance: The role of private ownership concentration, identity and board composition. Journal of Comparative Economics, 37 (4), 658673.

Rehman, R. ur, \& Mangla, I. U. (2012). Does Corporate Governance Influence Banking Performance? - ProQuest. Journal of Leadership, Accountability and Ethics 9.3, 86-92.

Sheikh, N. A., \& Karim, S. (2015). Effects of Internal Governance Indicators on Performance of Commercial Banks in Pakistan. Pakistan Journal of Social Sciences (PJSS), 35 (1), 77-90.

Shleifer, A. a. (1997, june). A Survey of Corporate Governance. Journal of Finance, 52, 737-783.

Yermack, D. (2005). "Higher Market Valuation of Companies with a Small Board of Directors". V Governance: An International Perspective, 1 , $150-176$. 